\title{
ANALISIS KESALAHAN SINTAKSIS DAN MORFOLOGIS KARANGAN BAHASA INGGRIS SISWA SMA BOPKRI I YOGYAKARTA
}

\author{
Mayang Widhi Pamulat Kristi dan Sugirin \\ Prodi Linguistik Terapan Pps UNY, Universitas Negeri Yogyakarta \\ Email: mayang.kristi@gmail.com,psugirin12@gmail.com
}

\begin{abstract}
ABSTRAK
Penelitian ini bertujuan mendeskripsikan kesalahan sintaksis dan morfologis pada karangan narrative, recount, dan procedure siswa kelas X SMA BOPKRI I Yogyakarta serta kemungkinan penyebabnya. Jenis penelitian ini adalah deskriptif-kualitatif yang menggunakan karangan siswa sebagai sumber data. Analisis data dilakukan dengan menggunakan taksonomi kesalahan (Dulay, 1982), teori penyebab kesalahan berbahasa (Richards, 1974), dan metode agih-padan. Hasil penelitian menunjukkan bahwa (1) siswa berprestasi tinggi dan sedang memiliki peluang kesalahan relatif sama, sedangkan siswa berprestasi rendah memiliki peluang kesalahan lebih tinggi; (2) kesalahan sintaksis paling dominan adalah kesalahan bentuk verba, yaitu penggunaan sistem kala, dan kesalahan morfologis paling dominan adalah penghilangan infleksi verba; (3) kesalahan yang mendapat prioritas utama perbaikan adalah kesalahan dengan frekuensi paling dominan serta kesalahan global yang berupa kesalahan susunan kata; (4) frekuensi kesalahan ketiga karangan siswa cukup tinggi dan sering terjadi dua kesalahan atau lebih dalam satu kalimat; dan (5) penyebab kesalahan adalah faktor antarbahasa dan faktor intrabahasa.
\end{abstract}

Kata kunci: analisis kesalahan, sintaksis, morfologis, implikasi, pembelajaran

\section{THE ANALYSIS OF SYNTACTIC AND MORPHOLOGICAL MISTAKES IN ENGLISH COMPOSITIONS OF THE STUDENTS OF YOGYAKARTA'S BOPKRI I HIGH SCHOOL}

\begin{abstract}
ABSTRAK
This research intends to describe the syntactic and morphological mistakes in the narrative, recount, and procedure compositions of the students of grade X in Yogyakarta's Bopkri I High School and the possible causes of the mistakes. A descriptive qualitative research, this study used students' compositions as its main data source, while the data analysis was conducted by using taxonomy of mistakes (Dulay, 1982), the theory of the causes of mistakes in using languages (Richards, 1974), and agih-padan method (distributional and identity methods). The research results show that: (1) students with high and medium levels of educational achievements have relatively the same opportunity of making mistakes, while students with low level of educational achievements have higher opportunity of making mistakes; (2) the most dominant syntactic mistakes are in the form of verbs, that is the use of tenses, and the most dominant morphological mistakes are in the form of the absence of verb inflections; (3) the most dominant mistakes and the global mistakes in the form of errors in word orders are given the first priority to be corrected; (4) the frequency of mistakes in the students' compositions is relatively high and there are often two or more mistakes in one sentence; and (5) the causes of the mistakes are interlanguage and intralanguage factors.
\end{abstract}

Keywords: error analysis, syntactic, morphological, implications, learning

\section{PENDAHULUAN}

Pembelajaran bahasa Inggris di Sekolah Menengah Atas (SMA) pada umumnya merupakan pembelajaran bahasa kedua (B2) yang terjadi setelah pemerolehan bahasa ibu (B1). Artinya, proses penguasaan B2 terjadi setelah siswa menguasai bahasa pertama dan melalui proses belajar bahasa (language learning). 
Dalam proses belajar B2, sangat dimungkinkan terjadi kesalahan-kesalahan (errors) di mana kesalahan-kesalahan tersebut dipandang sebagai hal yang tak terelakkan yang dilakukan siswa (Hidayati, 2011: 1-2).

Kesalahan dalam mempelajari B2 bisa disebabkan oleh beberapa faktor, diantaranya adalah kurangnya pemahaman siswa mengenai kaidah-kaidah B2. Adanya kontras-kontras lingual antara B1 dan B2 juga dapat menjadi sumber kesalahan. Dengan kata lain, adanya perbedaan antara struktur B1 dan struktur B2 diperkirakan sangat berpengaruh terhadap penguasaan B2. Artinya, apabila B1 memiliki struktur yang sangat berbeda dengan $B 2$, proses pembelajaran B2 akan cenderung semakin sulit (Tarigan, 2011: 19).

Kesulitan dan kegagalan yang dialami oleh peserta didik dalam proses pembelajaran B2 dapat terjadi dan atau terkait dengan keterampilan menulis. Keterampilan menulis dirasakan sulit untuk dikuasai oleh peserta didik karena keterampilan itu menuntut berbagai kompetensi yang menjadi prasyaratnya. Dalam proses menulis, tidak hanya diperlukan penguasaan kompetensi dasar seperti tata bahasa (grammar) dan kosa kata (vocabulary) namun juga melibatkan berbagai aspek kebahasaan seperti sandi tulisan, tata bunyi, tanda baca (punctuation), ejaan (spelling), dan sebagainya. Melalui pembelajaran menulis, siswa dilatih untuk terampil menerapkan beberapa aspek kebahasaan sehingga dapat menghasilkan tulisan yang baik.

Kesulitan penguasaan keterampilan menulis bahasa Inggris juga dialami oleh siswa kelas X SMA BOPKRI I Yogyakarta. Hal itu dibuktikan dengan masih banyak ditemukan kesalahan berbahasa pada produk tulisan siswa, di antaranya pada karangan narrative, recount, dan procedure. Kesalahan berbahasa siswa yang ditemukan pada tipe-tipe karangan tersebut pada umumnya berkenaan dengan aspek tatabahasa, yaitu aspek sintaksis dan aspek morfologis, seperti tampak pada kalimat siswa berikut ini.

(1) At the harbour, his mom see his with a women (his wife)....

Kalimat di atas menunjukkan adanya tiga jenis kesalahan. Yang pertama, siswa menggunakan bentuk verba kala kini see pada kon- struksi yang seharusnya menggunakan sistem kala lampau. Yang kedua, siswa menggunakan pronomina posesif his untuk menggantikan objek pronomina him. Dalam bahasa Inggris, pronomina akan berubah sesuai dengan perannya dalam kalimat. Jika berkedudukan sebagai objek, bentuk pronomina yang digunakan adalah me, you, us, them, him, her, it (Azar, 2003: 171). Karena subjek dalam kalimat itu adalah orang ketiga tunggal pria (yang ditandai dengan pemakaian frase his mom), objek pronomina yang digunakan adalah him. Yang ketiga, siswa menggunakan bentuk pembilang tunggal $a$ bersama kata women yang memiliki makna jamak. Dalam bahasa Inggris, terdapat kaidah persesuaian jumlah, di mana determinator tunggal haruslah diikuti dengan nomina tunggal pula (Eastwood, 1994: 220). Dengan demikian, frase a women merupakan frase yang melanggar kaidah itu. Agar sesuai dengan kaidah yang berlaku, frase $a$ women semestinya diubah menjadi frase $a$ woman. Berdasarkan penjelasan itu, kalimat (1) dapat dibetulkan menjadi At the harbour, his mom sawhim with a woman (his wife)....

Terjadinya kesalahan penghilangan atau penambahan unsur-unsur gramatikal seperti di atas, di satu sisi, menunjukkan kurangnya kompetensi bahasa Inggris siswa dan, di sisi lain, memungkinkan munculnya hambatan dalam mengikuti pembelajaran selanjutnya. Tatabahasa, yang mencakup aspek sintaksis dan morfologis, merupakan hal mendasar yang harus dikuasai oleh setiap pengguna bahasa, dan dalam hal ini, siswa diharapkan menyadari pentingnya penguasaan tatabahasa yang mengacu pada tatabahasa standar bahasa Inggris. Hal ini sesuai dengan pernyataan Greenbaum \& Nelson (2002: 5) bahwa

in the study of language, grammar occupies a central position...Knowing about grammar helps us understand what makes sentences and paragraphs clear and interesting and precise.

Artinya, dalam pembelajaran bahasa, tatabahasa menempati posisi pusat atau memegang peran penting. Pengetahuan tatabahasa yang baik dapat membantu siswa untuk memahami bagaimana menghasilkan kalimat-kalimat yang jelas, menarik, dan tepat. Dengan demikian, kesalahan tatabahasa dalam karangan siswa 
kelas X SMA BOPKRI I Yogyakarta merupakan masalah yang menuntut adanya upaya pemecahan/perbaikan mengingat bahwa aspek keakurasian (accuracy) adalah hal yang cukup penting dalam keterampilan menulis. Seperti dinyatakan Bailey (2006: 119) bahwa "accuracy is one aspect of the total fabric of good writing". Dengan kata lain, dalam pembelajaran menulis, ketepatan atau keakurasian setiap komponen bahasa dan setiap aspek tulisan merupakan aspek yang harus diperhatikan.

Upaya pemecahan/perbaikan kesalahan berbahasa dalam tulisan siswa, di antaranya, dapat diawali dengan analisis kesalahan berbahasa. Dari hasil wawancara dengan guru yang bersangkutan, diketahui bahwa upaya perbaikan kesalahan berbahasa siswa kelas X SMA BOPKRI I Yogyakarta belum dilakukan secara sistematis dan terencana. Dengan kata lain, upaya perbaikan atau remedial tidak dilakukan melalui proses identifikasi kesalahan, pencarian ranah dominasi kesalahan, serta pencarian sumber kesalahan secara rinci. Singkatnya, guru belum melakukan prosedur analisis kesalahan dalam melakukan perbaikan atau remedi.

Para pakar pembelajaran bahasa, pada umumnya, memandang analisis kesalahan berbahasa merupakan langkah penting yang harus dilakukan guru. Melalui analisis itu, berbagai aspek kebahasaan yang menjadi wilayah terjadinya kesalahan berbahasa serta dugaan penyebabnya dapat diidentifikasi dan dideskripsikan.

Salah satu model analisis kesalahan yang bisa digunakan untuk mengidentifikasi kesalahan berbahasa siswa adalah model analisis kesalahan Dulay (1982: 146). Model ini membagi jenis kesalahan berbahasa berdasarkan taksonomi-taksonomi, diantaranya taksonomi kategori linguistik, taksonomi siasat permukaan, dan taksonomi efek komunikatif. Taksonomi kategori linguistik digunakan untuk mengidentifikasi unsur linguistik apa saja yang dipengaruhi kesalahan; taksonomi siasat permukaan digunakan untuk mengidentifikasi kesalahan berdasarkan perubahan struktur unsur linguistik tertentu; dan taksonomi efek komunikatif digunakan untuk mengetahui apakah kesalahan berbahasa siswa sampai pada taraf mengganggu pemahaman pembaca atau tidak.
Selanjutnya, klasifikasi penyebab kesalahan dapat digunakan untuk mencari dan menentukan dugaan penyebab kesalahan siswa (Richards, et al., 1974: 69). Berdasarkan teori itu, kesalahan berbahasa dapat disebabkan oleh faktor antarbahasa (interferensi B1 terhadap B2) atau faktor intrabahasa (generalisasi berlebihan, pengabaian pembatasan kaidah B2, penerapan kaidah yang tidak sempurna, dan perumusan konsep yang keliru).

Hasil identifikasi dan deskripsi kesalahan berbahasa - berdasarkan taksonomitaksonomi di atas dan faktor penyebabnyadapat membantu guru untuk mengetahui jenis kesalahan siswa yang memiliki frekuensi tinggi dan perlu mendapat penekanan serta prioritas utama untuk segera diatasi (Khodabandeh, 2007: 15). Untuk itu, seluk-beluk terjadinya kesalahan berbahasa berdasarkan taksonomi Dulay, kemungkinan penyebab kesalahan berbahasa, dan alternatif pemecahannya harus dikaji secara mendalam serta hasilnya digunakan sebagai landasan dalam perencanaan pembelajaran berikutnya.

Pada akhirnya, pembelajaran bahasa yang disertai oleh atau dilandaskan pada upaya identifikasi kesalahan-kesalahan berbahasa siswa melalui analisis kesalahan berbahasa diharapkan dapat meningkatkan kualitas perencanaan dan pelaksanaan pembelajaran. Secara khusus, hasil penelitian ini diharapkan dapat dimanfaatkan sebagai masukan atau dasar pertimbangan bagi guru Bahasa Inggris di SMA BOPKRI I Yogyakarta dalam melakukan perbaikan kualitas pembelajaran, khususnya dalam kegiatan remedial. Diharapkan pula, hasil penelitian ini dapat memperkaya bukti-bukti empiris dalam pengembangan linguistik kontrastif, khususnya analisis kesalahan berbahasa.

\section{METODE}

Penelitian ini merupakan penelitian deskriptif-kualitatif yang bertujuan untuk mendeskripsikan suatu fenomena atau gejala kesalahan berbahasa pada karangan siswa sebagaimana adanya. Penelitian ini menghasilkan data deskriptif berupa kata-kata tertulis atau lisan dari sumber data yang dapat diamati (Moleong, 2006: 4) yang terkait dengan kesalahan sintaksis dan kesalahan morfologis pada 
karangan recount, narrative, dan procedure yang ditulis oleh siswa kelas X SMA BOPKRI I Yogyakarta.

Waktu dan Tempat penelitian

Penelitian ini dilakukan di SMA BOPKRI I Yogyakarta pada tahun pelajaran 2012/2013, semester kedua, Januari sampai Juni 2013.

Sumber Data dan Data Penelitian

Sumber data penelitian ini adalah karangan narrative, recount, dan procedure yang tersedia sebagai dokumen sekolah atau dokumen guru. Data penelitian ini adalah kesalahan sintaksis dan morfologis yang terjadi pada karangan siswa dan faktor penyebabnya.

Secara keseluruhan, sumber data itu berjumlah 690 yang terdiri dari 230 teks narative, 230 teks recount, dan 230 teks procedure,yang berasal dari sepuluh kelas paralel, yaitu kelas $\mathrm{X}$-A sampai kelas X-J. Pada kenyataannya, 690 sumber data itu tidak seluruhnya mendapatkan peluang untuk dikaji. Jenis dan jumlah riil karangan yang diteliti sebagai sumber data didasarkan pada dua pertimbangan, yaitu (1) kelompok siswa berdasarkan prestasi belajar bahasa Inggris dan (2) kejenuhan informasi atau data yang terdapat pada sumber data.

Dalam penelitian ini, titik jenuh masing-masing kelompok dan setiap jenis karangan itu berbeda-beda. Oleh karena itu, jumlah riil sumber data yang diperiksa atau diteliti, dalam rangka pengumpulan data, untuk masingmasing kelompok prestasi dan jenis karangan, juga berbeda-beda. Berdasarkan titik jenuh itu, jumlah karangan siswa yang dijadikan sumber data dapat dilaporkan sebagai berikut: (1) pada kelompok prestasi tinggi, titik jenuh terjadi pada jumlah sumber data maksimal 42 karangan, (2) pada kelompok prestasi sedang, titik jenuh terjadi pada jumlah sumber data maksimal 66 karangan, dan (3) pada kelompok prestasi rendah, titik jenuh terjadi pada jumlah sumber data maksimal 96 karangan. Dengan demikian, sumber data riil yang dikaji atau digunakan dalam penelitian berjumlah 240 karangan, baik karangan narrative, recount, maupun procedure.

Dalam penelitian ini digunakan pula sumber data yang lain, yaitu guru bahasa Inggris dan siswa kelas X SMA BOPKRI I Yogyakarta. Sebagai responden, keduanya merupakan sumber informasi yang terkait dengan kesalahan berbahasa dan faktor penyebab kesalahan; termasuk informasi yang berkenaan dengan proses pembelajaran.

Prosedur

Data penelitian dikumpulkan melalui observasi dan wawancara. Observasi dilakukan melalui teknik baca dan teknik catat. Teknik baca digunakan untuk mempelajari dengan seksama penggunaan bahasa siswa danuntuk menemukan kesalahan pada karangan siswa, baik sintaksis maupun morfologis. Teknik catat digunakan untuk mendokumentasikan data yang berupa kesalahan berbahasa (Sudaryanto, 2001: 139). Lebih lanjut, data yang berupa faktor yang melatarbelakangi kesalahan berbahasa dikumpulkan melalui wawancara, baik dengan siswa maupun guru.

Dalam mengumpulkan data, sebagai human instrument, peneliti menggunakan alat bantu yang berupa kisi-kisi - baik yang terkait dengan wujud dan klasifikasi kesalahan berbahasa maupun faktor-faktor penyebabnya - dan tabel data, seperti di bawah ini.

Kisi-kisi faktor penyebab kesalahan berbahasa siswa berdasarkan teori Richards (Richards, et al., 1974: 69)

Tabel 2. Kisi-kisi Faktor Penyebab Kesalahan Berdasarkan Teori Richards (1974)

\begin{tabular}{|c|c|}
\hline $\begin{array}{l}\text { Penyebab } \\
\text { Kesalahan }\end{array}$ & Keterangan \\
\hline Intrabahasa & Interferensi B1 \\
\hline Antarbahasa & $\begin{array}{l}\text { Generalisasi berlebihan } \\
\text { Pengabaian pembatasan kaidah B2 } \\
\text { Penerapan kaidah yang tidak } \\
\text { sempurna } \\
\text { Perumusan konsep yang keliru }\end{array}$ \\
\hline
\end{tabular}


Kisi-kisi klasifikasi kesalahan berbahasa berdasarkan taksonomi Dulay (1982, p.138)

Tabel 1. Kisi-kisi Klasifikasi Kesalahan Berdasarkan Taksonomi Dulay (1982)

\begin{tabular}{ccc}
\hline \multirow{2}{*}{ Taksonomi } & \multicolumn{2}{c}{ Jenis Kesalahan } \\
\cline { 2 - 3 } & Sintaksis & Morfologis \\
\hline \multirow{2}{*}{ Kategori linguistik } & Pembentukan frase & Infleksi \\
& Pembentukan klausa & Derivasi \\
& Persesuaian & \\
& Penggunaan konjungsi & \\
Susunan kata & \\
Siasat permukaan & Perubahan (transformation) & Penghilangan \\
& Fungsi kalimat (sentence fragment) & Penambahan \\
& Penghilangan & Salah bentuk \\
& Penambahan & Salah susun \\
Efek komunikatif & Salah bentuk & Penggantian \\
& Salah susun & Lokal \\
& Penggantian & Global \\
\hline
\end{tabular}

Kisi-kisi wawancara

Tabel 3. Kisi-kisi Wawancara

\begin{tabular}{cl}
\hline \multicolumn{1}{c}{ Faktor } & \multicolumn{1}{c}{ Sub-faktor } \\
\hline Pembelajaran & $\begin{array}{l}\text { a. Materi sudah dipelajari atau } \\
\text { belum } \\
\text { b. Materi sudah terpahami atau } \\
\text { belum }\end{array}$ \\
Materi & $\begin{array}{l}\text { a. Aspek sintaksis } \\
\text { b. Aspek morfologis }\end{array}$ \\
Metode & $\begin{array}{l}\text { a. Metode dan assesment guru } \\
\text { efektif atau tidak }\end{array}$ \\
pembelajaran & $\begin{array}{l}\text { b. Metode guru mudah diikuti } \\
\text { atau tidak }\end{array}$ \\
Kesalahan & $\begin{array}{l}\text { Kesalahan atau kekeliruan } \\
\text { Faktor }\end{array}$ \\
Motivasi, minat, dan gaya belajar \\
internal siswa & siswa
\end{tabular}

Tabel data analisis kesalahan

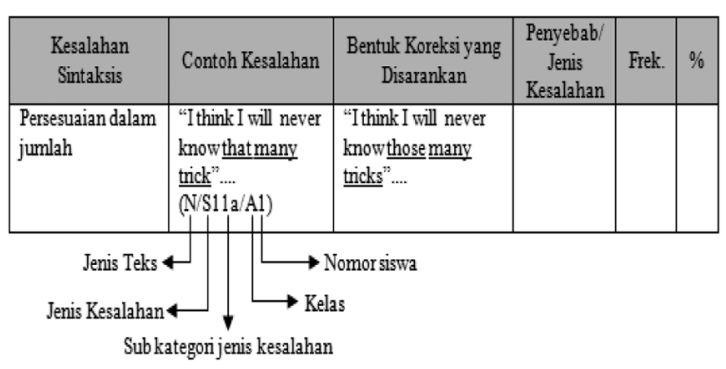

Gambar 1.

Contoh Tabel Data Analisis Kesalahan

Tabel data di atas dilengkapi dengan sejumlah keterangan dan kodifikasi, yaitu (a) kode sumber data yang terdiri atas jenis karangan, jenis kesalahan, kelas serta nomor siswa, (b) contoh kesalahan, (c) letak kesalahan, (d) bentuk koreksi yang disarankan, (e) jenis kesalahan, (f) penafsiran faktor penyebabnya, $(\mathrm{g})$ frekuensi kesalahan, dan (h) persentase kesalahan

Teknik analisis data

Analisis data dalam penelitian ini berkenaan dengan kegiatan mengumpulkan data kesalahan, mengidentifikasi kesalahan, menjelaskan kesalahan, mengklasifikasi kesalahan, dan mengevaluasi kesalahan (Ellis, 1987: 15-20). Langkah-langkah itu juga dilakukan terkait dengan faktor-faktor penyebab terjadinya kesalahan. Dalam melakukan langkah-langkah analisis data itu, digunakan taksonomi kesalahan (Dulay, et al., 1982: 146), klasifikasi penyebab kesalahan (Richards, et al., 1974, p.69), serta metode agih dan padan (Sudaryanto, 2001: 36-40).

Taksonomi kesalahan yang digunakan dalam penelitian ini terdiri dari taksonomi kategori linguistik, taksonomi siasat permukaan, dan taksonomi efek komunikasi. (1) Taksonomi linguistik digunakan untuk mengetahui apakah kesalahan itu terdapat pada tingkat kata, frase, klausa, atau kalimat. (2) Taksonomi siasat permukaan digunakan untuk mengetahui bentuk perubahan struktur kata, frase, klausa, dan kalimat, yaitu apakah kesalahan berupa penghilangan, penambahan, penggantian, salah bentuk, atau salah susun. (3) Taksonomi efek komunikatif 
digunakan untuk mengetahui efek kesalahan sintaksis dan morfologis terhadap proses komunikasi dan atau pemahaman pembaca, yaitu apakah kesalahan termasuk kesalahan lokal (tidak mengganggu proses pemahaman pesan) atau termasuk kesalahan global (mengganggu proses pemahaman pesan). Taksonomi ini juga digunakan untuk mengetahui jenis kesalahan yang harus segera diperbaiki atau dikoreksi.

Klasifikasi penyebab kesalahan digunakan untuk mencari dugaan penyebab kesalahan siswa. Berdasarkan teori Richards, kesalahan berbahasa dapat disebabkan oleh faktor antarbahasa (interferensi B1 terhadap B2) atau faktor intrabahasa (generalisasi berlebihan, pengabaian pembatasan kaidah B2, penerapan kaidah yang tidak sempurna, dan perumusan konsep yang keliru).

Lebih lanjut, metode agih, yang sering dipadankan dengan metode distribusional, digunakan dengan memanfaatkan beberapa teknik: (1) teknik substitusi digunakan untuk menentukan kesanggupan suatu satuan lingual digantikan oleh unsur lain; (2) teknik permutasi digunakan untuk menentukan kesanggupan atau potensi suatu unsur untuk dipindahkan posisinya dalam suatu konstruksi; (3) teknik sisip digunakan untuk menentukan potensi satuan lingual untuk dipisahkan dari satuan lingual yang lain dalam sebuah konstruksi; (4) teknik delisi digunakan untuk menentukan potensi satuan lingual untuk dilepas atau dihilangkan dari suatu konstruksi; dan (5) teknik perluasan digunakan untuk menentukan potensi suatu satuan lingual untuk disandingkan dengan satuan lingual yang lain dalam sebuah perluasan konstruksi.

Di samping metode agih atau distribusional, digunakan pula metode padan mengingat bahasa yang diteliti juga memiliki hubungan dengan hal-hal di luar bahasa. Dalam hal ini, digunakan teknik pilah unsur penentu (PUP), yaitu dengan melihat susunan larik tulisan dan melihat sifat dan watak aneka langue. Daya pilah pembeda sifat dan watak aneka langue digunakan dalam menganalisis struktur serta pemilihan kata bahasa Inggris (B2) dalam kaitannya dengan bahasa ibu (B1) siswa. Untuk melakukan pekerjaan itu, prinsip-prinsip analisis kontrastif digunakan sebagai dasar pertimbangan.

\section{HASIL DAN PEMBAHASAN}

Melalui pengumpulan dan analisis data, ditemukan frekuensi dan persentase kesalahan sintaksis dan kesalahan morfologis pada teks siswa seperti berikut ini.

Tabel 4. Frekuensi dan Persentase Kesalahan Berbahasa pada Karangan Siswa

\begin{tabular}{ccccc}
\hline \multirow{2}{*}{ Teks } & \multicolumn{2}{c}{ Jenis Kesalahan } & \multirow{2}{*}{ Frek. } & \multirow{2}{*}{$\%$} \\
\cline { 2 - 4 } & Sintaksis & Morfologis & & \\
\hline Narrative & 744 & 379 & 1.123 & 44 \\
Recount & 787 & 221 & 1.008 & 39 \\
Procedure & 358 & 69 & 427 & 17 \\
Jumlah & $1.889^{*}$ & 669 & 2.558 & 100 \\
\hline
\end{tabular}

Tabel 4 menunjukkan bahwa ada 2.558 kesalahan yang ditemukan pada ketiga jenis karangan siswa yang meliputi 1.889 kesalahan sintaksis dan 669 kesalahan morfologis. Dengan demikian, dapat disimpulkan bahwa kesalahan yang paling dominan adalah kesalahan sintaksis.

Berdasarkan Taksonomi Kategori Linguistik, kesalahan sintaksis pada ketiga karangan siswa yang secara keseluruhan berjumlah 1.889 itu meliputi 504 kesalahan yang berkenaan dengan pemakaian frase nominal, 952 kesalahan yang berkenaan dengan pemakaian frase verbal, 15 kesalahan yang berkenaan dengan pemakaian frase adverbial, 174 kesalahan yang berkenaan dengan pemakaian frase preposisional, 9 kesalahan yang berkenaan dengan pemakaian klausa relatif, 1 kesalahan yang berkenaan dengan pemakaian adjektiva komparatif, 46 kesalahan yang berkenaan dengan transformasi, 39 kesalahan yang berkenaan dengan susunan kata, 87 kesalahan yang berkenaan dengan pemakaian fungsi kalimat, 10 kesalahan yang berkenaan dengan subjek-pronomina, dan 52 kesalahan yang berkenaan dengan pemakaian konjungsi. Di antara kesalahan sintaksis di atas, yang paling dominan adalah kesalahan yang berkenaan dengan pemakaian frase verbal,yaitu sebanyak 952 kesalahan. Hal itu dapat ditunjukkan melalui Grafik 2. 


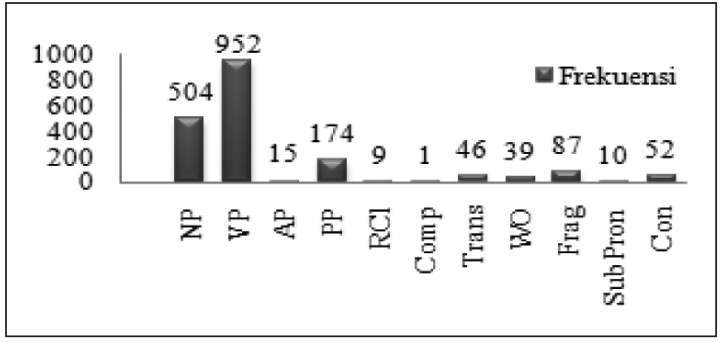

Gambar 2. Grafik Kesalahan Sintaksis

Keterangan:

NP (Frase nominal)

VP (Frase verbal)

AP (Frase adverbial)

PP (Frase preposisional)

$\mathrm{RCl}$ (Klausa relatif)

Comp (Adjektiva komparatif)

Trans (Transformasi)

WO (Susunan kata)

Frag (Fungsi kalimat)

Con (Konjungsi)

Sub pron (Subjek-pronomina)

Kesalahan pemakaian frase verbal yang berjumlah 952 di atas didominasi oleh kesalahan bentuk verba yang terkait dengan penggunaan sistem kala (misformation of verbs due to tenses) pada konteks yang bersangkutan. Kesalahan itu dapat berupa salah bentuk verba seperti pada kalimat berikut ini.

(2) I thinked this is more my story about holidays. (R/S1a3/B1)

Penggunaan verba thinked pada kalimat (2) menunjukkan dua hal. Pertama, siswa menganggap bahwa verba think adalah bentuk verba-teratur(regular verb), sehingga akhiran $\{-e d\}$ dapat ditambahkan pada verba itu. Kedua, siswa menggunakan verba bentuk kala lampau untuk konteks yang seharusnya menggunakan verba bentuk kala kini. Kedua hal itu membuat kalimat menjadi tidak berterima.Agar menjadi bentuk yang berterima, kalimat (2) semestinya diubah menjadi I think this is my story about my holiday.

Kesalahan penambahan akhiran $\{-e d\}$ juga dapat dilihat pada contoh (3).

(3) So he ranned to his house, and the house really get burnt down, then he becomes poor. (N/M2b2/G3)

Pada contoh (3), siswa berasumsi bahwa semua verba bentuk kala lampau harus menggunakan akhiran $\{-e d\}$, sehingga akhiran itu ditambahkan pada verba-tidak-teratur ran. Guru mengatakan bahwa pola-pola seperti pada kalimat (3) sering ditemukan dalam tulisan siswa. Hal ini menunjukkan bahwa beberapa siswa masih kurang memahami kaidah perubahan bentuk verba kala lampau, khususnya verba tidak-teratur (irregular verb), sehingga mereka cenderung menyamaratakan penggunaan akhiran $\{-e d\}$ pada semua verba bentuk kala lampau.

Kesalahan seperti pada kalimat (2) dan (3) disebabkan oleh adanya generalisasi berlebihan. Generalisasi berlebihan adalah kondisi di mana siswa menciptakan struktur yang menyimpang oleh karena pengalamannya mengenai struktur terdahulu dalam B2 (Richards, 1974, p.174). Dengan kata lain, siswa menerapkan pengalamannya mengenai struktur terdahulu pada situasi baru yang tidak sama.

Generalisasi berlebihan dapat dipicu oleh adanya perumusan konsep yang keliru akibat penerapan metode pembelajaran yang tidak tepat atau tidak efektif. Berdasarkan hasil wawancara, dalam proses pembelajarannya, guru bahasa Inggris kelas X menerapkan metode terjemahan tatabahasa (grammar translation method) di mana proses belajar dan mengajar berisi kegiatan-kegiatan dan latihan penerjemahan teks dari bahasa sasaran ke bahasa ibu atau sebaliknya. Siswa biasanya diberi tugas untuk mengartikan teks dari bahasa Indonesia ke bahasa Inggris, atau sebaliknya. Dalam hal ini, siswa mempelajari tatabahasa secara deduktif, yaitu pertama-tama guru mengajarkan kaidah-kaidah gramatikal bahasa Inggris beserta contoh-contohnya, kemudian siswa diminta untuk menghafal dan menerapkan contoh-contoh itu pada tes tertulis yang telah disediakan. Tes tertulis juga sering diberikan dalam bentuk terjemahan dari B1 ke B2 atau sebaliknya.

Penerapan metode terjemahan tatabahasa seperti ini, di satu sisi, dapat mengembangkan kemampuan siswa dalam seni penerjemahan, sekaligus dapat memperkaya kosakata, namun, di sisi lain, dapat mengakibatkan adanya generalisasi berlebihan. Latihan-latihan yang disediakan guru mengenai kaidah gramatikal dapat menyebabkan kaidah-kaidah tumpang tindih, sehingga siswa menggeneralisasi kaidahkaidah itu, atau menerapkan kaidah yang satu 
pada konteks yang lain yang tidak sama. Hal itu sesuai dengan pernyataan Richards (1974, p.173) bahwa siswa menciptakan struktur yang menyimpang karena pajanan (exposure) mereka yang terbatas mengenai struktur atau kaidah yang berbeda pada B2. Akibatnya, siswa secara otomatis menerapkan kaidah tertentu pada konteks yang tidak membutuhkannya.

Kesalahan pada frase verbal yang ditemukan pada karangan siswa tidak hanya disebabkan oleh generalisasi berlebihan. Kesalahan pada frase verbal juga bisa disebabkan oleh perumusan konsep yang keliru, seperti pada kalimat berikut ini.

(4) Olla, Bigel, how are you? I hope you'll fine. (R/S1a2/J7)

Kesalahan yang terjadi pada kalimat (4) menunjukkan bahwa pemahaman siswa mengenai sistem verba bantu bahasa Inggris masih rendah. Kalimat itu menggunakan sistem kala progresif yang ditandai oleh penggunaan bentuk are pada konstruksi kalimat tanya Olla, Bigel, how are you? Artinya, kalimat tanya itu menunjukkan keinginan penulis untuk mengetahui kondisi pembacanya, yaitu Bigel. Agar menjadi kalimat yang berterima, modal will pada pernyataan I hope you will fine sebaiknya dihilangkan dan diganti dengan bentuk lain, yaitu are. Dengan demikian, kalimat (4) seharusnya dinyatakan seperti berikut ini: Olla, Bigel, how are you? I hope you are fine.

Contoh lain kesalahan frase verbal yang disebabkan oleh perumusan kaidah yang keliru dapat dilihat pada kalimat berikut ini:

(5) I am remember when we went to the mall and spent one day together there. (R/Slal) F7)

Pada kalimat (5), kerancuan konsep terjadi pada pemakaian verba bantu am pada konstruksi I am remember untuk konstruksi yang seharusnya $I$ remember. Pola seperti ini diduga sebagai akibat dari anggapan siswa bahwa kalimat (5) merupakan bentuk kalimat progresif, di mana kegiatan 'mengingat' sedang dan masih berlangsung pada saat ia menulis teks itu. Kesalahan itu menunjukkan bahwa siswa belum memahami kaidah pembentukan verba simple present tense. Menurut tatabahasa bahasa Inggris, bentuk be dapat digunakan dalam konstruksi simple present tense jika bentuk itu berperan atau berfungsi sebagai kopula (verba penghubung). Jika di dalam kalimat sudah ada verba utama (main verb), misalnya remember, verba utama itu tidak perlu ditambah dengan bentuk be. Dengan demikian, kalimat (5) semestinya diubah menjadi I remember when we went to a mall and spent a day together there.

Lebih lanjut, ditemukan pula kasus kesalahan seperti pada kalimat berikut ini.

(6) I hope you Ø happy read my last holiday. (R/S1b1/H3)

Berdasarkan kaidah tatabahasa bahasa Inggris, present progressive tense seperti kalimat (6) dibentuk dari unsur be (is, am, are) dan partisipel kala kini (present participle) atau verba bentuk-ing (Azar, 2003, p.4). Tidak adanya verba bantu pada contoh kalimat (6) di atas menunjukkan bahwa siswa belum sepenuhnya memahami dan mampu menerapkan kaidah itu. Agar menjadi bentuk yang berterima, di dalam kalimat (6) harus ditambahkan verba bantu yang sesuai. Bentuk verba bantu yang tepat untuk subjek you pada kalimat itu adalah are.

Selain tidak hadirnya verba bantu, kalimat itu juga menunjukkan hilangnya infleksi partisipel \{-ing\} sebagai penanda bentuk verba present progressive tense. Pemakaian bentuk 'read' menjadi tidak tepat karena konteks kalimat itu mengharuskan penggunaan infleksi $\{$-ing $\}$ pada verba itu, untuk mengindikasikan sistem kala present continous. Dengan demikian, bentuk yang seharusnya digunakan adalah reading, sehingga kalimat (6) dapat dibetulkan menjadi I hope you are happy reading about my last holiday story.

Kaidah-kaidah sintaksis seperti di atas bersifat menentukan persesuaian bentuk antarkata yang mengisi struktur sintaksis yang bersangkutan. Artinya, struktur sintaksis tertentu, misalnya yang menampakkan hubungan antara subjek dan verba, mengharuskan adanya persesuaian bentuk morfologis kata-kata yang mengisi struktur sintaksis itu. Sebagai contoh, subjek orang ketiga tunggal pada bentuk kala kini (present tense) menuntut hadirnya verba dasar dengan akhiran infleksi $\{-s\}$ atau $\{-e s\}$. Sebaliknya, jika subjek itu orang pertama tunggal atau orang kedua atau ketiga jamak, verba yang mengikutinya tidak diberi akhiran $\{-s\}$ atau $\{-e s\}$. Dengan demikian, bentuk morfologis 
verba harus disesuaikan dengan bentuk subjeknya. Kaidah-kaidah persesuaian antara struktur sintaksis dan bentuk morfologis kata-kata yang mengisinya juga dipengaruhi oleh sistem kala. Sebagai contoh, apabila secara sintaksis menunjukkan kala lampau, bentuk mofologis verbanya harus dalam bentuk lampau.

Penjelasan di atas mengandung makna bahwa aspek sintaksis dan morfologis sesungguhnya merupakan satu kesatuan yang tidak terpisahkan. Hal ini diperkuat dengan temuan bahwa kesalahan morfologis yang secara keseluruhan berjumlah 669 didominasi oleh kesalahan pembentukan verba seperti ditunjukkan melalui Grafik 3.

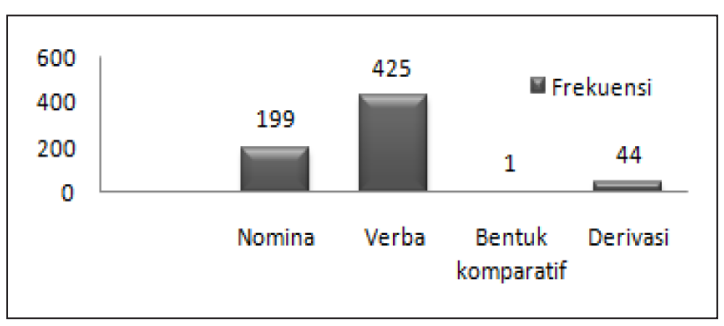

Gambar 3. Grafik Kesalahan Morfologis

Tingginya kesalahan infleksi verba pada tataran morfologis selaras dengan kesalahan pada tataran sintaksis yang juga didominasi oleh kesalahan sistem kala pada verba. Hal itu dapat dimaklumi karena pada dasarnya persoalan morfologi suatu bahasa tidak terlepas dari persoalan sintaksis, atau sebaliknya. Sebuah kata akan mendapatkan kejelasan bentuk, kategori, fungsi, dan perannya setelah kata itu digunakan di dalam struktur sintaksis. Setiap kata yang hadir di dalam struktur sintaksis tertentu selalu menampakkan hubungan sintagmatis tertentu yang bersifat saling menentukan. Persesuaian antara subjek dan verba yang menyertainya serta persesuaian antara bentuk verba dan sistem kala merupakan bukti adanya hubungan sintagmatis antarunsur dalam suatu konstruksi sintaksis.

Pada tataran morfologis, kesalahan pembentukan verba didominasi oleh penghilangan infleksi pada verba, seperti pada kalimat berikut ini.

(7) We have home in Jakarta because my father work there. (R/M2a/H7)

Hilangnya infleksi $\{-s\}$ pada kalimat (7) mengakibatkan kalimat itu menjadi tidak berterima. Sistem persesuaian antara subjek dan verba (subject-verb agreement) dalam bahasa Inggris menuntut adanya perubahan struktur morfologis verba tertentu. Subjek anak-kalimat pada kalimat itu adalah my father (orang ketiga tunggal) sehingga verba yang mengikutinya harus mendapatkan infleksi $\{-s\}$ seperti berikut ini: We have a house in Jakarta because my father works there.

Kesalahan morfologis seperti di atas diduga disebabkan oleh interferensi bahasa pertama siswa. Dalam bahasa Indonesia tidak dikenal adanya sistem persesuaian subjek dan predikat verba (subject-verb agreement). Verba pergi dalam kalimat Tina pergi ke pasar setiap hari dan Tina pergi ke pasar kemarin tidak mengalami perubahan meskipun menggunakan penanda waktu yang berbeda. Demikian pula, penggunaan Tina sebagai subjek yang berupa orang ketiga tunggal tidak menuntut persesuaian pada predikat verbanya. Dengan kata lain, predikat verba itu memiliki bentuk yang sama, baik untuk subjek orang pertama, kedua, maupun ketiga, baik tunggal maupun jamak. Pengalaman berbahasa seperti itu diduga diterapkan dalam berbahasa Inggris, sehingga sistem persesuaian antara subjek dan predikat verba dalam bahasa Inggris diabaikan. Akibatnya, verba bahasa Inggris mengalami penghilangan infleksi $\{-s\}$ atau $\{-e s\}$, seperti pada kalimat (7).

Kesalahan penghilangan infleksi pada verba juga dapat dilihat pada kalimat di bawah ini.

(8) Last month I follow DIAN PINSAD the scout training. (R/M2b1/G2)

Penggunaan sistem kala lampau (past tense) menuntut adanya perubahan struktur morfologis verba, yaitu dengan penambahan infleksi $\{-e d\}$ atau $\{-d\}$ pada bentuk dasarnya. Kalimat (8) menggunakan penanda waktu last month yang mengindikasikan bahwa kalimat itu menyatakan kejadian pada masa lampau, yaitu pengalaman siswa pada waktu mengikuti sebuah pelatihan. Dengan demikian, verba follow pada kalimat itu harus mendapatkan infleksi $\{-e d\}$, sehingga kalimat itu menjadi seperti berikut ini: Last month, I followed DIAN PINSAD, the scout training.

Kesalahan-kesalahan berbahasa siswa yang telah dipaparkan di atas dapat dilihat 
berdasarkan Taksonomi Efek Komunikatif. Taksonomi ini mengklasifikasikan kesalahan menjadi kesalahan lokal dan kesalahan global. Kesalahan lokal adalah kesalahan yang mempengaruhi sebuah unsur kalimat tetapi masih dapat dipahami oleh pembaca (atau pendengar). Kesalahan global merupakan bentuk kesalahan yang mempengaruhi keseluruhan organisasi kalimat, sehingga pembaca sulit untuk menangkap pesan atau makna yang terkandung di dalam kalimat itu. Kesalahan global termasuk jenis kesalahan yang membutuhkan penanganan serius karena termasuk kesalahan fatal walaupun penanganan itu harus dilakukan pada saat atau situasi yang tepat (Tarigan, 2011: 176).

Kesalahan penghilangan, penambahan, dan penggantian, serta salah bentuk verba (baik secara sintaksis maupun morfologis) seperti yang telah dipaparkan di atas termasuk ke dalam kesalahan lokal. Artinya, kesalahan itu tidak begitu mengganggu proses pemahaman pesan. Pembaca masih mampu menafsirkan dan memahami pesan yang disampaikan melalui kalimat yang dibacanya.

Burt \& Kiparsky (Tarigan, 2011, p.162) memandang bahwa kesalahan lokal seperti itu tidak membutuhkan perbaikan secara intensif atau segera. Dalam hal ini, apabila yang menjadi tujuan pembelajaran menulis adalah kelancaran (fluency), perspektif kesalahan lokal seperti itu masih bisa dipahami relevansinya. Namun, jika pembelajaran menulis juga ditekankan pada perspektif keakurasian (accuracy), setidaknya ada keseimbangan antara kelancaran dan keakurasian, perspektif bahwa kesalahan lokal dapat diabaikan perlu dipertimbangkan lebih lanjut.

Seperti telah dikemukakan dalam latar belakang masalah, dalam pembelajaran menulis, ketepatan atau keakurasian setiap komponen bahasa dan setiap aspek tulisan merupakan salah satu aspek yang harus diperhatikan. Tuntutan keakurasian dalam bahasa tulis berbeda dengan bahasa lisan. Jika dalam pemakaian bahasa lisan tindakan non-verba bisa sangat membantu proses pemahaman, dalam pemakaian bahasa tulis, hal itu tidak bisa terjadi. Dalam pemakaian bahasa tulis, proses pemahaman yang dilakukan pembaca benar-benar hanya mengandalkan lambang atau simbol tertulis. Oleh karena itu, ketepatan dalam hal aspek sintaksis dan mor- fologis benar-benar menjadi persyaratan kegramatikalan dan menjadi penentu pemahaman pesan dalam pemakaian bahasa tulis (Fahrudin, 1996: .8).

Walaupun kesalahan lokal dipandang sebagai kesalahan berbahasa yang tidak begitu mengganggu proses komunikasi, bukan berarti bahwa dalam proses pembelajaran menulis kesalahan lokal itu dapat diabaikan. Kesalahan lokal yang sangat banyak tentu saja akan memiliki kecenderungan yang relatif tinggi dalam mengganggu proses pemahaman pesan. Apalagi jika di dalam satu kalimat yang ditulis siswa terdapat dua atau lebih kesalahan seperti pada kalimatkalimat berikut ini:

(9) In the garden the girl playing with bird, butterfly but the giant come to the girl and was to eat she. (N/MG/C2)

Kalimat (9) menunjukkan adanya beberapa kesalahan. Pertama, siswa menggunakan verba playing dan come untuk bentuk verba kala lampau played dan came. Kedua, siswa menggunakan bentuk verba bantu was yang tidak sesuai untuk digunakan dalam konteks itu. Dalam bahasa Inggris, verba bantu seperti was tidak dapat berdiri sendiri. Ketiga, siswa menggunakan tanda baca koma di antara nomina bird dan butterfly. Jika keduanya merupakan unsur yang setara, unsur yang semestinya hadir di antara kedua nomina itu adalah konjungsi and (bukan koma). Selain itu, jika kedua nomina itu masingmasing bersifat tunggal, yang diperlukan ialah determinator. Jika kedua nomina itu bersifat jamak, yang diperlukan penanda jamak, yaitu infleksi $\{\mathrm{s}\}$. Yang terakhir, siswa menggunakan pronomina persona she untuk menggantikan objek pronomina her.

Kasus kesalahan yang bersifat kesalahan-ganda atau bahkan multi-kesalahan seperti pada contoh di atas menunjukkan bahwa siswa masih mengalami kesulitan yang cukup serius, sehingga membutuhkan perhatian guru. Lagi pula, kesalahan itu tidak hanya dialami oleh siswa yang termasuk dalam kelompok berprestasi rendah, tetapi juga dialami oleh siswa yang termasuk dalam kelompok berprestasi sedang dan tinggi.

Berdasarkan hasil temuan, kelompok siswa yang berprestasi sedang dan tinggi relatif sering melakukan kesalahan. Sekadar contoh, 
Tabel 5. Sebaran Kesalahan Sintaksis Berdasarkan Kelompok Prestasi Siswa

\begin{tabular}{llcccc}
\hline \multirow{2}{*}{ No } & \multirow{2}{*}{ Kesalahan Sintaksis } & \multicolumn{3}{c}{ Kelompok Prestasi } & \multirow{2}{*}{ Jumlah } \\
\cline { 3 - 5 } & & Tinggi & Sedang & Rendah & \\
\hline 1 & Frase nominal & 104 & 140 & 260 & 504 \\
2 & Frase verbal & 215 & 271 & 466 & 952 \\
3 & Frase adverbal & 1 & 3 & 11 & 15 \\
4 & Frase preposisional & 29 & 47 & 98 & 174 \\
5 & Klausa relatif & 4 & 3 & 2 & 9 \\
6 & Bentuk komparatif & 0 & 0 & 1 & 1 \\
7 & Transformasi & 12 & 11 & 23 & 46 \\
8 & Susunan kata & 5 & 9 & 25 & 39 \\
9 & Fungsi kalimat & 19 & 30 & 38 & 87 \\
10 & Subjek pronomina & 1 & 3 & 6 & 10 \\
11 & Konjungsi & 13 & 7 & 32 & 52 \\
\hline & Jumlah & 403 & 524 & 962 & 1.889 \\
& $(\%)$ & 21 & 28 & 51 & 100 \\
\hline
\end{tabular}

Tabel 6. Sebaran Kesalahan Morfologis Berdasarkan Kelompok Prestasi Siswa

\begin{tabular}{cccccc}
\hline \multirow{2}{*}{ No } & \multirow{2}{*}{ Kesalahan Morfologis } & \multicolumn{3}{c}{ Kelompok Prestasi } & \multirow{2}{*}{ Jumlah } \\
\cline { 2 - 5 } & Tinggi & Sedang & Rendah & \\
\hline 1 & Nomina & 35 & 42 & 122 & 199 \\
2 & Verba & 102 & 123 & 200 & 425 \\
3 & Bentuk komparatif & 0 & 0 & 1 & 1 \\
4 & Derivasi & 14 & 12 & 18 & 44 \\
\hline & Jumlah & 151 & 177 & 341 & 669 \\
& $\%$ & $23 \%$ & $26 \%$ & $51 \%$ & $100 \%$ \\
\hline
\end{tabular}

untuk siswa yang termasuk kelompok sedang, frekuensi kesalahan dalam pembentukan frase verbal sebanyak 271 kali. Untuk siswa yang termasuk kelompok tinggi, frekuensi kesalahan dalam pembentukan frase verbal sebanyak 215 kali. Dalam kasus yang lain, kelompok berprestasi tinggi bahkan mengalami kesalahan yang lebih tinggi daripada kelompok berprestasi sedang seperti yang dikemukakan pada Tabel 5.

Melalui Tabel 5, dapat dilihat bahwa kelompok siswa berprestasi tinggi lebih sering melakukan kesalahan bentuk transformasi transformasi bentuk pasif dan bentuk tanya dan pemakaian konjungsi dibandingkan siswa berprestasi sedang.

Seperti halnya pada kasus kesalahan sintaksis, pada kasus kesalahan morfologis, kelompok siswa berprestasi sedang dan tinggi juga relatif sering melakukan kesalahan. Yang perlu mendapat perhatian di sini adalah kelompok siswa berprestasi tinggi juga mengalami kesalahan yang lebih tinggi daripada kelompok siswa berprestasi sedang dalam hal bentuk derivasi seperti yang ditunjukkan pada Tabel 6 .
Kasus-kasus seperti di atas tentu saja perlu segera ditangani secara serius. Data yang ditunjukkan oleh beberapa tabel hasil penelitian di atas dapat menjadi bahan pertimbangan guru dalam melakukan remedial dan perbaikan pembelajarannya lebih lanjut.

Kesalahan lain yang perlu ditangani secara serius berdasarkan perspektif Taksonomi Efek Komunikatif adalah kesalahan global. Jenis kesalahan global yang ditemukan dalam ketiga karangan siswa adalah kesalahan penempatan dan ketidaklengkapan fungsi sintaksis (subjek, predikat, objek, pelengkap, keterangan) pada konstruksi klausa, kesalahan susunan atau urutan kata, tidak hadirnya unsur inti sebuah frase, ketidaktepatan pemilihan konjungsi, dan kesalahan penempatan konjungsi, yang secara keseluruhan mencapai 207 kasus. Dari keseluruhan kasus itu, kesalahan global yang paling dominan adalah kesalahan susunan kata yang terjadi sebanyak 39 kali, di antaranya, seperti ditunjukkan pada contoh di bawah ini.

(10) And then the giant had give seed cucumber. $(\mathrm{N} / \mathrm{S} 12 / \mathrm{C} 2)$ 
(11) Milkshake chocolate $\varnothing$ ready to serve (P/ S12/D7)

Kesalahan susunan kata seperti ditunjukkan pada contoh kalimat di atas berkenaan dengan pola DM (diterangkan-menerangkan) yang berlaku di dalam bahasa Indonesia dan pola MD (menerangkan-diterankan) yang berlaku di dalam bahasa Inggris. Di dalam bahasa Indonesia, frase nominal dibentuk dengan pola DM. Frase mawar merah terdiri dari mawar sebagai unsur yang diterangkan dan merah sebagai unsur yang menerangkan atau modifikator. Pola seperti itulah yang diduga diterapkan siswa, sehingga di dalam contoh kalimat di atas, berturut-turut, terdapat konstruksi frase seed cucumber dan milkshake chocolate. Di dalam bahasa Inggris, pola yang berlaku adalah MD. Artinya, modifikator mendahului nomina yang merupakan inti frase. Agar berterima, konstruksi frase seed cucumber dan milkshake chocolate harus diubah urutannya menjadi cucumber seed dan chocolate milkshake. Dengan demikian, kedua kalimat itu dapat dibetulkan menjadi And then the giant gave a cucumber seed dan The chocolate milkshake is ready to serve.

Lebih lanjut, kesalahan susunan kata juga terjadi di dalam kalimat-kalimat berikut ini.

(12) That small house in the stayed Cinderella, with two stepsisters and step mother. (N/ S12/A6)

(13) ...so we slept at school over. (R/S14/D3)

(14) Then, wait the soup until boil and the soup ready to serve. (P/S12/I4)

Kesalahan susunan kata seperti yang terjadi pada kalimat (12), (13), dan (14) menunjukkan bahwa siswa belum memahami dan belum bisa menerapkan pola pikir bahasa Inggris. Siswa kurang memahami kata yang seharusnya hadir lebih dahulu dan kata yang harus hadir sesudahnya. Berdasarkan hasil wawancara dengan guru bidang studi yang bersangkutan, kesalahan susunan kata dengan pola seperti itu sering terjadi pada tulisan siswa yang prestasinya rendah. Artinya, siswa yang prestasinya rendah belum memahami bahwa pola urutan kata yang terjadi pada ketiga kalimat itu harus diubah menjadi pola urutan kata seperti yang terdapat pada kalimat (12a), (13a), dan (14a) berikut ini. (12a) In that small house stayed Cinderella with two stepsisters and a step mother.

(13a) ...so we slept over at school.

(14a) First, boil the water and wait until the water gets hot then put the noodle and the dori fish in it, wait until it is medium done.

Taksonomi Efek Komunikatif memandang kesalahan-kesalahan global seperti di atas sebagai kesalahan yang sebaiknya mendapat prioritas utama dalam perbaikan. Pada umumnya, kesalahan global merupakan kesalahan yang sulit untuk diatasi sendiri oleh siswa, sehingga guru perlu memberikan 'bantuan' yang relevan terhadap kesulitan siswa itu. Upaya perbaikan dapat dilakukan secara klasikal oleh guru apabila kasus kesalahan itu dialami oleh sebagian besar siswa. Setiap kasus kesalahan global dipresentasikan, dikaji bersama, dan dicarikan pemecahan bersama.

Secara ringkas, hasil penelitian di atas, termasuk implikasinya dalam pembelajaran, dapat dikemukakan melalui simpulan berikut ini.

\section{SIMPULAN}

Hasil penelitian menunjukkan bahwa (1) siswa berprestasi tinggi dan sedang memiliki peluang kesalahan yang relatif sama, sedangkan siswa berprestasi rendah memiliki peluang kesalahan lebih tinggi. Dalam beberapa kasus ditemukan siswa berprestasi tinggi mengalami frekuensi kesalahan yang lebih tinggi daripada siswa berprestasi sedang; (2) kesalahan sintaksis yang paling dominan adalah kesalahan bentuk verba terkait dengan penggunaan sistem kala dan kesalahan morfologis yang paling dominan adalah penghilangan infleksi pada verba; (3) kesalahan yang sebaiknya mendapat prioritas utama perbaikan adalah kesalahan dengan frekuensi paling dominan serta kesalahan global yang berupa kesalahan susunan kata; (4) frekuensi kesalahan dalam ketiga karangan siswa cukup tinggi dan sering terjadi dua kesalahan atau lebih dalam satu kalimat; dan (5) yang menjadi penyebab kesalahan adalah faktor antarbahasa, yaitu interferensi, dan faktor intrabahasa, yaitu generalisasi berlebihan, pengabaian pembatasan B2, penerapan kaidah yang tidak sempurna, dan perumusan kaidah yang keliru. 
Hasil penelitian ini dapat digunakan oleh guru sebagai rambu-rambu dalam memprediksikan kesulitan belajar dan kesalahan berbahasa yang mungkin dialami siswa dalam pembelajaran bahasa kedua, khususnya dalam keterampilan menulis. Misalnya, banyaknya kesalahan yang terjadi pada aspek morfologis merupakan indikator bahwa siswa masih mengalami banyak kesulitan dalam menggunakan berbagai bentuk kata secara kolokatif. Berdasarkan temuan itu, guru bisa melakukan langkah-langkah diagnostik dan preventif. Secara diagnostik, guru bisa melakukan 'penyembuhan' terhadap berbagai kesulitan yang dihadapi siswa dan secara preventif guru bisa merencanakan pembelajaran berikutnya yang lebih efektif bagi siswa. Demikian pula dalam hal kesalahan-kesalahan sintaksis.

Hasil penelitian ini juga dapat digunakan oleh guru sebagai bahan pertimbangan dalam menyusun rencana perbaikan atau remidial yang tepat berdasarkan tingkat kesalahan yang paling dominan yang dilakukan siswa dengan mempertimbangkan klasifikasi kesalahan lokal dan global. Dalam hal ini, kesalahan global sebaiknya mendapat perhatian yang lebih besar dan mendapatkan penanganan lebih dahulu daripada kesalahan-kesalahan lokal. Hal itu bukan berarti kesalahan lokal tidak penting untuk ditangani. Dalam penelitian ini ditemukan kesalahan lokal yang terjadi lebih dari satu kali dalam sebuah kalimat. Hal itu berpotensi menjadi penyebab terjadinya kesulitan pemahaman kalimat. Walaupun termasuk kategori kesalahan lokal, kasus itu sebaiknya juga mendapatkan perhatian dalam pembelajaran, mengingat keakurasian bahasa dalam menulis merupakan hal yang cukup penting. Dengan demikian, guru dapat menentukan skala prioritas dalam melakukan remidial atau perbaikan.

\section{Ucapan Terima Kasih}

Artikel ini disusun berdasarkan tesis yang telah diujikan dan direvisi. Oleh karena itu, saya mengucapkan terima kasih kepada pembimbing Prof. Dr. Sugirin dan dewan penguji tesis yang telah memberi masukkan dan saran terhadap tesis saya. Dengan bantuan tersebut artikel hasil penelitian ini dapat diwujudkan.

\section{DAFTAR PUSTAKA}

Azar, B.S. 2003. Fundamentals of English gram$\operatorname{mar}\left(3^{\text {rd }}\right.$ ed.). New York: Longman.

Bailey, S. 2006. Academic Writing: a Handbook for International Students ( $2^{\text {nd }}$ ed.). New York: Routldege.

Dulay, et al. 1982. Language Two. Oxford: Oxford University Press.

Eastwood, J. 1994. Oxford Guide to English Grammar. Oxford: Oxford University Press.

Ellis, R. 1987. Second Language Acquisition. Oxford: Oxford University Press.

Fahrudin, A. E. 1996. Meningkatkan Kemampuan Menulis. Yogyakarta: Andi Offset.

Greenbaum, S. \& Nelson, G. 2002. An Introduction of English Grammar (2 $2^{\text {nd }} e d$.). London: Pearson Education Limited.

Hidayati, S. 2011. Error Analysis on a Short Speech: A Case Of An ESL Indonesian Learner. E-CLUE (Journal of English Culture, Language, Literature, and Education) English Department, Manado State University, 5 (1), 1-2.

Moleong, L. J. 2006. Metodologi Penelitian Kualitatif. Bandung: PT. Remaja Rosdakarya.

Richards, et al. 1974. Error Analysis: Perspective on Second Language Acquisition. London: Longman Group Limited.

Sudaryanto. 2001. Metode dan aneka teknik analisis bahasa. Yogyakarta: Duta Wacana University Press.

Tarigan. 2011. Pengajaran Analisis Kesalahan Berbahasa. Bandung: Angkasa. 